\title{
KRÁTKÝ EXKURZ DO HISTORIE KONFERENČNÍHO TLUMOČENÍ V BÝVALÉM ČESKOSLOVENSKU A DNEŠNÍM ČESKU ANEB ZAMYŠLENÍ NAD NĚKTERÝMI PARADOXY NA TRHU TLUMOČENÍ A V PŘíPRAVĚ BUDOUCÍCH PROFESIONÁLNÍCH TLUMOČNÍKŮ
}

\section{IVANA ČEŇKOVÁ}

If you talk to a man in a language he understands, that goes to his head. If you talk him in his language, that goes to his heart.

(Nelson Mandela)

\section{Kontext}

V letošním roce 2019 si konferenční tlumočníci na celém světě, ale zejména v Evropě, připomínají 100 let od oficiálního uznání této profese. Stalo se tak v roce 1919 na mírové konferenci v Pařriži, pořádané vítězi první světové války, kde po celou dobu využívali služeb tlumočníků, aby - tehdy ještě pouze konsekutivně - tlumočili mezi angličtinou a francouzštinou veškerá jednání mezi vítěznými mocnostmi a poraženými státy. Angličtinu si prosadila Velká Británie, jelikož do té doby diplomatická a politická jednání probíhala $\mathrm{v}$ Evropě vždy pouze ve francouzštině. Jedním z nepřímých výsledků mírové smlouvy, podepsané ve Versailles po šesti měsících vyjednávání, bylo i založení Společnosti národů a také např́íklad Mezinárodní organizace práce (MOT) - obě se sídlem v Ženevě -, jež zajistily práci mnoha konferenčním tlumočníkům po celé meziválečné období. V roce 1928 se právě v sídle MOT na jejich výroční konferenci testovala i první technická aparatura firmy IBM a první kabiny pro simultánní tlumočení, které zahájilo své vítězné tažení po celém světě o několik let později, během Norimberského soudního procesu (1945-1946) a následně se začalo pravidelně používat na zasedáních Valného shromáždění Organizace spojených národů (OSN), která vznikla po druhé světové válce v roce 1945 a nahradila tak svoji nepř́liš úspěšnou předválečnou předchůdkyni - Společnost národů. Postupně se simultánní tlumočení prosadilo ve všech mezinárodních a evropských organizacích či strukturách, včetně Evropských společenství (ES), jež byla založena v roce 1957 Ř́mskými smlouvami a která si ve svých zakládajících dokumentech stanovila, že všichni její občané (v roce 1993 se Evropská společenství transformovala $\mathrm{v}$ Evropskou unii - EU) mohou komunikovat s orgány a úřady Evropských společenství, respektive Evropské unie v oficiálních jazycích jednotlivých členských států. V současné době (listopad 2019) Evropská unie má 24 oficiálních jazyků a 28 členských států. Stejně 
tak i mezinárodní odborné konference, jichž se po 2. světové válce začalo pořádat stále více a kde mohli účastníci hovořit během svých vystoupení ve stanovených pracovních jazycích dané akce, využívaly a využívají pravidelně služeb konferenčních tlumočníků a kabinové tlumočení.

Všechny tyto změny si vyžádaly i nové přístupy v přípravě a vzdělávání budoucích konferenčních tlumočníků. Je známo, že první tlumočnické vysokoškolské studijní obory vznikají již v průběhu 2. světové války (Ženeva 1941, Vídeň 1942), ale většina tlumočnických škol je zakládána až v poválečném období. V tehdejším Československu je studijní obor tlumočnictví (a překladatelství) ustaven v roce 1963 na Univerzitě 17. listopadu a v roce 1974 následně po rozpuštění této univerzity je celý obor převeden jako Katedra překladatelství a tlumočnictví na Filozofickou fakultu Univerzity Karlovy (FF UK), kde tento obor zakotvil nastálo - od roku 1993 již jako Ústav translatologie (ÚTRL) a kde jsou připravováni konferenční tlumočníci jak pro domácí soukromý či institucionální trh, tak třeba i pro evropské instituce.

\subsection{Postskriptum namísto úvodu}

Mým cílem není podrobný popis všech tlumočnických škol ani tlumočnických situací a ani všech změn, ke kterým došlo, nýbrž se chci pokusit glosovat některé paradoxy, které vnímám při pohledu „do zpětného zrcátka“ vlastní čtyřicetileté praxe konferenční tlumočnice a téměř pětatřicetiletého pedagogického působení v Praze na Univerzitě Karlově spojeného s př́pravou budoucích tlumočníků. Uvědomila jsem si je právě v souvislosti s výše uvedeným stoletým výročím konferenčního tlumočení. Rozhodla jsem se - a je to čistě můj osobní názor, který nikoho jiného nezavazuje -, že se podívám na těch uplynulých 40 let tak trochu s humorem a někdy i se špetkou ironie, jelikož se na mnohé skutečnosti či paralely často zapomíná. Pokusím se velmi stručně porovnat trh tlumočení v tehdejším Československu a dnešní České republice, členském státě Evropské unie a NATO. Okomentuji krátce některé aspekty didaktiky a př́pravy tlumočníků na Ústavu translatologie FF UK, dnes s využitím informačních technologií, digitalizace, všemocného a „vševědoucího“ internetu a se zjevnými změnami na globálním trhu práce, a srovnám je s možnostmi, které jsme měli při výcviku budoucích tlumočníků v minulosti, kdy ještě nebyl internet ani další moderní technologické vymoženosti, ale ani kopírka či třeba fax, natož chytrý mobilní telefon nebo kvalitní osobní počítač, laptop nebo tablet.

\section{Trh konferenčního tlumočení v předlistopadovém Československu}

V 70. a 80. letech 20. století působily na pražském (českém) trhu tlumočení dvě tlumočnické agentury, které zajištovaly veškeré zakázky pro tlumočníky: Konferenční servis Mezinárodní organizace novinářů (MON) a Pražská informační služba (PIS) a její překladatelsko-tlumočnické oddělení. V tehdejším Československu sídlila řada mezinárodních „bratrských“ organizací, mimo jiné již zmíněná Mezinárodní organizace novinářů (MON), Mezinárodní svaz studentů (MSS), Světová odborová organizace (SOF), Křestanská mírová konference (KMK) a pochopitelně další organizace, stranické orgány či 
vládní instituce také na svých zasedáních či jednáních s partnerskými delegacemi a při častých zahraničních cestách potřebovaly vždy tlumočení.

\subsection{Pilotáž, tlumočení do aktivního cizího jazyka a tlumočení na dálku}

Paleta žádaných jazyků byla značná, a tak se často tlumočilo dvoustupňově, tj. s pilotáží - přes pilotní kabinu (relay) - a tlumočení do cizího jazyka (retour) bylo také na denním pořádku (Čeňková 2015a).

V roce 1981 byl slavnostně otevřen Palác kultury v Praze (dnešní Kongresové centrum), kde se měly odehrávat zejména sjezdy Komunistické strany Československa a kde byly pro všechny sály (velký, malý, společenský) instalovány stálé tlumočnické kabiny, na tu dobu velmi prostorné a vybavené moderní tlumočnickou technikou, včetně malého černobílého televizoru. V červnu 1983 se zde konalo Světové shromáždění za mír a život, proti jaderné válce, kterého ze zúčastnili delegáti ze 132 zemí, a jednání probíhala v 11 pracovních skupinách, kde bylo vždy zajištěno simultánní kabinové tlumočení (kromě obvyklých jazyků, tj. ruštiny, francouzštiny, angličtiny, němčiny a španělštiny zde byla např́klad i arabština), a mnohdy docházelo ke kuriózním situacím, kdy řečník hovořil např́klad vietnamsky a do kabiny v tu chvíli přišel vietnamský tlumočník, který přijel jako doprovod se svým delegátem, s vytištěným francouzským překladem, a ukazoval nám „on-line“, kde se právě řečník v textu nachází, a my jsme tak tlumočili simultánně s textem pro ostatní tlumočníky jako pilotní kabina do češtiny s tím rozdílem, že jsme netušili, co v daném okamžiku zní v originále. Přesto řada zahraničních delegátů musela své vystoupení číst v cizím jazyce, jelikož tlumočení do/z jejich mateřštiny nemohlo být zajištěno. A tak se tlumočníci vypořádávali s mnoha cizími př́ízvuky a někdy i se zcela gramaticky a foneticky nesrozumitelnými projevy.

Československý režim si chtěl uspořádáním tohoto Shromáždění zvýšit mezinárodní prestiž a před vlastním obyvatelstvem se prezentovat jako respektovaný člen celosvětového společenství. Jednalo se přitom o jakousi náhražkovou světovost, která měla zakrýt neúprosný úpadek Prahy i celého Československa do guberniální provinciálnosti. Jednání Světového shromáždění za mír a život, proti jaderné válce se mělo účastnit asi 3000 lidí z celého světa, především mírových aktivistů. Akci poslal zdravici i tehdejší generální tajemník OSN Jávier Pérez de Cuellar a jejími hlavními hvězdami byli předseda Světové rady míru Ind Rómeš Čandra nebo předsedkyně Mezinárodní ženské ligy za mír a svobodu Edith Ballantyneová. Nechyběl ani třeba slavný řecký skladatel a politik Mikis Theodorakis. Mezi zahraničními účastníky jednoznačně dominovali prokomunisticky či prosovětsky orientovaní aktivisté. ${ }^{1}$

Proč zmiňuji právě tuto akci? Protože její příprava, respektive př́íprava celého početného tlumočnického týmu, který zajištoval Konferenční servis MON, byla na tu dobu neuvěřitelně pečlivá a důsledná. Tlumočníci se museli zúčastnit školení (v dnešní terminologii by se nejspíše jednalo o briefing), kde se probírala a vysvětlovala hlavně př́slušná slovní zásoba, ale i politické otázky: jaké jsou výzvy a cíle této akce, kdo jsou účastní-

1 Citováno z: https://www.ceskatelevize.cz/porady/10266819072-vypravej/ve-stopach-doby/1983/352 -v-praze-probehlo-svetove-shromazdeni-za-mir-a-zivot-proti-jaderne-valce [access: 29. 11. 2019]. 
ci a vůbec celý širší geopolitický kontext a byl vypracován tištěný interní vícejazyčný tematicky uspořádaný glosár. Postupně nám pak byly dodávány nezbytné konferenční materiály, př́ípadně jednotlivá vystoupení, pokud je řečníci dodali včas. Dnes bychom si asi vše museli dohledat na internetu a jednotlivé projevy, seznamy účastníků a program bychom obdrželi zřejmě od organizátorů pouze elektronicky.

$\mathrm{V}$ té době měla valná většina řečníků vždy předem připravené a napsané projevy (často i někým jiným), které pak četla ve velmi vysokém tempu. Jistě vám to něco připomíná, že? Po menší pauze koncem 80 . a počátkem 90 . let, kdy nastoupila zcela nová generace politiků a noví lidé přicházeli i do všech sfér života republiky, řečníci najednou uměli hovořit spatra, „bez papíru“, pouze na základě svých poznámek či bodů. Mluvili jasně, srozumitelně a bylo možné sledovat logiku jejich vystoupení a s přehledem tak podat kvalitní tlumočnický výkon. Dnes však již opět naprosto převládá čtení připravených projevů, často ve zběsilém tempu, při kterém nelze vnímat obsah projevu ani v originále, natož při jeho tlumočení. Nejvíce je tato tendence v současnosti patrná na jednáních evropských institucí, kdy při postupně rostoucím počtu členských států je čas vymezený pro každého delegáta stále kratší. A zástupce členského státu chce stihnout říci vše, co si napsal a k projednávanému bodu připravil, či co mu bylo experty připraveno, a proto se to snaží přednést, respektive přečíst co nejrychleji, aby se do časového limitu vešel. Že tím trpí jak př́mí posluchači, tak ti, kteří poslouchají tlumočení, je evidentní.

Již jsem zmínila, že v tehdejším Paláci kultury byly v kabinách nainstalovány černobílé televizní monitory - jednak proto, aby tlumočníci lépe viděli na různé prezentace a vůbec na řečníka, jelikož tzv. velký sál, kolem kterého byly v patře umístěny vestavěné kabiny, byl skutečně obrovský. Ale i proto, že mnohdy se samotné zasedání, které se simultánně tlumočilo, konalo ve zcela jiné místnosti, a jediný kontakt s řečníky zprostředkovával právě tento malý černobílý televizor. Vrcholem všeho pak byly zcela bizarní situace, kdy před čelním sklem kabin v sále probíhala třeba zkouška nějakého divadelního představení nebo koncertu a vy jste přes monitor sledovali a tlumočili vysoce odbornou konferenci ze sálu o dvě patra níže. Takže na remote tlumočení neboli tlumočení na dálku byli čeští tlumočníci v té době zvyklí a připravení (Čeňková 2008b). A proto o řadu let později, již po sametové revoluci a po zapojení se do tlumočnických aktivit v rámci AIIC či v evropských strukturách, naši tlumočníci ne vždy zcela chápali, proč tlumočení na dálku vzbuzuje u kolegů z Evropy tolik obav, protestů a nevůle. Dnes je situace již opět o velký krok dál, tlumočení na dálku si získává postupně své místo na slunci a setkáváme se s ním stále častěji, jak v evropských či mezinárodních institucích, tak i na soukromém trhu. Byly definovány standardy pro jeho použití (tlumočníci musí mít k dispozici na velkoplošných monitorech záběry z jednacího sálu, nejlépe v několika „oknech“ tak, aby viděli na řečníka, na celý sál, na svého delegáta i na předsedajícího) a zvuk musí splňovat veškeré parametry kvality.

\subsection{Tlumočení v rámci Rady vzájemné hospodářské pomoci a Varšavské smlouvy}

Rada vzájemné hospodářské pomoci (RVHP) byla založena v roce 1949 jako reakce na Marshallův plán neboli Plán evropské obnovy, který byl přijat Kongresem USA dne 3. dubna 1948 s cílem organizovaně zabezpečit americkou pomoc poválečné Evropě. 
Protože SSSR a země východního bloku nabídku odmítly, byl plán omezen na západní Evropu. V době největšího rozkvětu měla RVHP 11 členů (Bulharsko, Československo, Polsko, Mad’arsko, Rumunsko, SSSR, Albánie, NDR, Mongolsko, Kuba, Vietnam) a dalších 13 států mělo status pozorovatele či přidruženého člena. RVHP ukončila svoji činnost v červnu 1991. Pro srovnání zmíním, že v přibližně stejném období se Evropská společenství skládala ze 12 členských států.

Tzv. Smlouva o přátelství, vzájemné pomoci a spolupráci neboli Varšavská smlouva byla podepsána v roce 1955 mezi sedmi státy tehdejšího východního bloku (Sovětský svaz - SSSR, Německá demokratická republika - NDR, Československo - ČSSR, Polsko, Mad’arsko, Bulharsko a Rumunsko. Albánie jako jeden ze zakládajících členů Varšavské smlouvy opustila její řady v roce 1968. Vojenská organizace Varšavská smlouva vznikla v reakci na vstup Spolkové republiky Německa do Severoatlantické aliance (NATO). $\mathrm{V}$ čele Varšavské smlouvy stál vždy vysoký vojenský představitel Sovětského svazu. Také Varšavská smlouva byla rozpuštěna v roce 1991.

V žádném př́ipadě nemám v úmyslu hodnotit činnost těchto dvou organizací, zajímá mne pouze a výlučně jejich jazyková politika a práce tlumočníků. Vycházím přitom z osobních výpovědí a vzpomínek kolegů tlumočníků, kteří pro tyto organizace tehdy tlumočili, a to jak simultánně, tak konsekutivně. Kabinové tlumočení ve všech (většině) jazyků členských států bylo zajištováno na zasedáních nejvyšších představitelů, kde pilotním jazykem byla ruština, na jednání na nižší úrovni, tj. na jednání expertů, si delegace vozily své tlumočníky, kteří tlumočili jednak konsekutivně, jednak používali šušotáž, tj. tlumočili simultánně šeptem do ucha svému delegátovi. Hlavním jednacím jazykem byla $\mathrm{v}$ té době pochopitelně ruština, která v této části Evropy měla na zasedáních vlastně stejnou roli jako určitá lingua franca. Vidíme, že dnešní situace není opět nic až tak nového pod sluncem. Jediný drobný rozdíl je možná v tom, jak si ten který jazyk získal své postavení jako lingua franca.

\section{Ad: Vysokoškolská příprava českých tlumočníků tehdy a dnes}

V souvislosti s popisovaným dobovým kontextem se zde zaměřím pouze na hlavní změny, ke kterým v průběhu uplynulých čtyřiceti let ve vysokoškolském vzdělávání českých tlumočníků došlo (Čeňková 1995, 2000).

\subsection{Technické vybavení, nahrávky a rodilí či nerodilí mluvčí}

Situace na tehdejším domácím trhu tlumočení jasně ukázala, že tlumočníci musí být připraveni na tlumočení řečníků, kteří nehovoří vždy svou mateřštinou, čtou rychle předem připravené psané projevy a musí zvládat tlumočit oběma směry: jak do češtiny, tak do cizího jazyka (retour). Pokud je na vícejazyčné konferenci zajištěno kabinové simultánní tlumočení, tak často tlumočníci pracují přes pilotní kabinu (relay) a navíc mohou být kabiny umístěny zcela mimo zasedací místnost. Budoucí tlumočníky bylo potřeba na všechny tyto situace připravit. V 70.-80. letech jsme jako studenti neměli k dispozici skutečné tlumočnické kabiny, ale tlumočení jsme si trénovali v jazykové laboratoři u stolků 
s malými přepážkami, kde seděl každý student sám a tlumočil s velkými zvukotěsnými sluchátky na hlavě. Pracovalo se zejména s magnetofonovými nahrávkami projevů různých politiků a odborníků, anebo vyučující četl, respektive oralizoval novinové články či vystoupení, jež měl k dispozici vytištěné či vystřižené z denního tisku. Rodilých mluvčích bylo poskrovnu, a tudíž vyučující vystupoval jak v češtině, tak ve svém cizím pracovním jazyce. Když se na trhu objevily diktafony (walkmany), mohli se studenti i nahrávat a poslechnout si zpětně své tlumočení. Postupně se začaly více využívat i videozáznamy na kazetách VHS, které si pro potřeby výuky nahrávali z televize sami vyučující anebo fakultní technik, který dostal konkrétní zadání. Skutečnou tlumočnickou laboratoř získalo naše pracoviště díky evropskému projektu až v roce 1992. Tím, že se tehdy pracovalo zejména s audionahrávkami, byli studenti vlastně velmi dobře připraveni na to, čemu se dnes ř́ká tlumočení na dálku (remote interpreting) a co stále vyvolává tolik nevole mezi konferenčními tlumočníky a jejich profesními organizacemi. Stejně tak byli studenti zvyklí tlumočit nerodilé mluvčí a tlumočit oběma směry, tj. do mateřštiny i do cizího jazyka, jelikož v té době nebylo vưbec snadné získat a zapojit do výuky rodilé cizojazyčné vyučující, navíc takové, kteří by měli povědomí o tom, na co je potřeba se při tlumočení do cizího jazyka a při jeho hodnocení především soustředit.

Studenti dostali časem možnost trénovat tlumočení i v rámci samostudia, kde měli postupně k dispozici bohatou audio- a videotéku s nahrávkami, jež pro ně pořizovali vyučující zejména na konferencích a akcích, na kterých sami tlumočili, či je získali od kolegů nebo z jiných univerzit, z televize, rozhlasu, mezinárodních organizací apod. Když jsme nedávno tyto kazety likvidovali - jelikož dnes je vše již digitalizováno a vše potřebné najdete přímo na internetu, či si stáhnete do počítače, na externí disk nebo někam na virtuální úložiště -, tak jsem si dala práci a spočítala je. Ten počet byl opravdu impozantní. Celkem měli studenti na samostudiu k dispozici 95 audiokazet s anglickými nahrávkami, 50 kazet s češtinou, 44 kazet ve francouzštině, 37 s němčinou, 33 s ruštinou a 24 se španělštinou. Počítám-li, že každá kazeta obsahuje 90 minut nahrávek různých projevů a vystoupení, dostaneme se na 424 hodin nahrávek. Pokud jde o videokazety, tak těch jsem napočítala celkem 300 (odborné pořady, besedy, diskuse, kulaté stoly, konference, dokumenty, pedagogické projevy z Generálního ředitelství konferenčního tlumočení Evropské komise DG SCIC, ale i hrané filmy), což představuje asi 900 hodin materiálu. Jen tak pro zajímavost, jako vyučující jsem sama měla doma pro výuku tlumočení na audiokazetách dalších asi 600 hodin projevů a vystoupení v ruštině, češtině a francouzštině. Dnes je pochopitelně situace diametrálně odlišná, existují různé virtuální databáze „pedagogických“ nahrávek, at už náš DAVID², či zejména Speech Repository 2.0, kterou vybudovalo a stále doplňuje - i s pomocí tlumočníků a vyučujících z tlumočnických univerzit - právě DG SCIC a která je dána k dispozici studentům tlumočnických oborů partnerských univerzit. Nebo i další elektronické platformy či zdroje a videa přímo na internetových stránkách různých institucí a organizací, Youtube, TED talks apod., abych vyjmenovala alespoň některé současné možnosti. Studentům lze poslat nahrávku v digitální podobě elektronicky či jim ji uložit někam na cloud, aby si ji stáhli, znovu přetlumočili, nahráli se a poslali výsledek zpět vyučujícímu nebo spolužákovi k hodnocení.

2 www.david.ff.cuni.cz [access: 30. 11. 2019]. 
Po roce 1989, když se otevřely hranice a Ústav translatologie FF UK začal aktivně spolupracovat s dalšími zahraničními tlumočnickými univerzitami v Evropě, se na nás zpočátku kolegové na západních univerzitách dívali poněkud kriticky, že učíme studenty retour i při simultánním tlumočení, že pracujeme s audionahrávkami, a ne „živými“ řečníky a že používáme nerodilé mluvčí. Stejně jako naši kolegové vyučující tlumočení z dalších středoevropských zemí jsme argumentovali tím, že naše málo rozšířené jazyky si nemohou tento luxus dovolit a že situace na trhu tlumočení je taková, že tlumočníci musí pracovat oběma směry a že dnes a denně se setkávají při práci s nerodilými mluvčími. Zároveň nám všem bylo jasné, že i jinde na soukromém trhu je situace obdobná a že i tam tlumočníci musí pracovat oběma směry, aby měli zakázky (Godijns - Hinderdael 2005).

Česká republika se od 90. let začala také intenzivně připravovat na své budoucí členství v Evropské unii, včetně výcviku dalších konferenčních tlumočníků, kteří by pak měli a mohli v institucích EU tlumočit (Čeňková 2007a, b, c). Ještě před naším vstupem do EU (2004) se ukázalo, že při tlumočení v evropských institucích je při tak velkém počtu oficiálních jazyků dosti často potřeba tlumočit přes pilotáž a zároveň tlumočit do cizího aktivního jazyka. Tudíž dosti rychle naše (západní) partnerské univerzity přehodnotily svůj negativní postoj k výuce retouru při simultánním tlumočení, stejně tak i k tomu, že je potřeba zvládat i nerodilé mluvčí s často zcela nesrozumitelným přízvukem či nesprávnou větnou stavbou, kteří se snaží používat zejména angličtinu jako lingua franca, ač mají zajištěné tlumočení a mohou jak mluvit ve své mateřštině, tak poslouchat projevy ostatních také ve své mateřštině. ${ }^{3}$ Ale o tom si můžete přečíst podrobně i v jiných publikacích, věnujících se právě problematice tlumočení v evropských institucích a přípravě tlumočníků pro tento segment trhu.

\section{2 Ústav translatologie inovuje své studijní plány}

Při přípravě tlumočníků i náš Ústav translatologie FF UK pravidelně přicházel a přichází s dalšími a dalšími inovacemi ve výuce tlumočení, z nichž se nám řadu z nich podařilo postupně akreditovat, a staly se pevnou součástí studijních plánů oboru Tlumočnictví. Jako členové prestižního EMCI Konsorcia (European Masters in Conference Interpreting) 16 evropských univerzit již od roku 1999 pravidelně pořádáme roční intenzivní postgraduální kurz EMCI (Čeňková 2000), který jsme v roce 2016 akreditovali jako specializační modul v rámci 2. ročníku navazujícího magisterského studijního oboru Tlumočnictví pro naše nejmotivovanější a nejlepší studenty. Jsme si zcela vědomi toho, že společnost, technologie, druhy akcí i způsoby tlumočení se vyvíjejí mílovými kroky a že je potřeba na tyto změny studenty a budoucí tlumočníky připravit. Pracujeme ve výuce s různými digitálními platformami, pořádáme pravidelně simulované konference na různá aktuální témata, kde studenti simultánně tlumočí a tvoří jeden společný tým,

3 Viz: EMCI Workshop (2002) Teaching Simultaneous Interpretation into a B language vol 1: https:// www.emcinterpreting.org/emci_drupal_data/EMCI-TeachingSimultaneousIntoB-vol1.pdf [access: 29. 11. 2019].

EMCI Workshop (2005) Teaching Simultaneous Interpretation into a B language vol 2: https://www .emcinterpreting.org/emci_drupal_data/EMCI-TeachingSimultaneousIntoB-vol2.pdf [acess: 29. 11. 2019]. 
stř́idají se v kabině s kolegy, pomáhají si, pilotují a musí pro „zahranični“ účastníky tlumočit do pracovních jazyků dané konference, jelikož ti nerozumí česky a chtějí sledovat jednotlivá vystoupení ve své mateřštině. Studenti zároveň vystupují jako řečníci i jako aktivní publikum konference. S partnerskými univerzitami a s DG SCIC či DG LINC (Generální ředitelství konferenčního tlumočení Evropského parlamentu) organizujeme videokonference s konsekutivním tlumočením: řečníci i hodnotitelé jsou na druhé straně obrazovky, v Bruselu a studenti tlumočí v naší tlumočnické laboratoři, kde máme nainstalováno videokonferenční zařízení. Díky těmto videokonferencím a také díky tzv. virtuálním návštěvám řečníků a hodnotitelů si studenti zvykají na nečekané stresové situace a učí se tlumočit v režimu remote, což je, jak už jsem psala výše, jeden z nově se prosazujících způsobů tlumočení na dálku. Díky modulu EMCI jsme navýšili počet hodin přímé řízené výuky konsekutivního i simultánního tlumočení (bez textu i s textem), tam, kde je to možné, vyučující pracují v tandemu (tj. jsou nasazeni dva vyučující, kteří tak pokryjí jako rodilí mluvčí příslušnou jazykovou kombinaci), s možností, že při závěrečné zkoušce ze simultánního tlumočení se student rozhodne (zejména na základě doporučení svých vyučujících), že cizí jazyk bude nabízet bud' jako aktivní jazyk, nebo pasivní (tj. student tlumočí u zkoušky pouze do mateřštiny) a takto bude mít svoji jazykovou kombinaci vyznačenou i na doplňku k diplomu. Dnes má Ústav translatologie $\mathrm{k}$ dispozici dvě moderní tlumočnické učebny vybavené veškerými informačními a digitálními technologiemi, každou se šesti dvojitými kabinami a naší snahou je kombinovat při výuce simultánního tlumočení práci s nahrávkami (audio i video) a „živé “ řečníky. Studenti mají možnost v rámci povinně volitelných předmětů vyjet na odbornou tlumočnickou exkurzi do evropských institucí do Bruselu, kde tři dny tlumočí na skutečných zasedáních Evropské komise, Rady či Evropského parlamentu v tzv. němých kabinách, tj. s vypnutým mikrofonem a pod dohledem a hodnocením českých stálých tlumočníků, $\mathrm{z}$ nichž je drtivá většina právě našimi absolventy. V rámci kurzu Konferenční teorie a pra$x e$ se studenti podrobně a konkrétně připravují na to, jak nejlépe se prosadit a uplatnit na trhu práce, na vyjednávání s př́mým soukromým nebo institucionálním klientem či tlumočnickou agenturou, na to, jak nejlépe se připravit na odbornou akci, jak získat a nastudovat materiály, jak sestavit tlumočnický tým a spolupracovat s kolegy v kabině, jak zvládat stres, jak využít marketing a sebeprezentaci ve svůj prospěch, jak vycházet na konferenci s techniky, kteří mají na starost kabiny, zda a jak se zapojit do života odborné tlumočnické komunity a stát se členem profesní organizace, jak dodržovat etický kodex apod. O všech těchto otázkách a aspektech diskutují s pozvanými hosty - většinou s našimi absolventy, kteří aktivně pracují jako profesionální tlumočníci, se zástupci profesních organizací (ASKOT - Asociace konferenčních tlumočníků, JTP - Jednota tlumočníků a překladatelů, KST ČR - Komora soudních tlumočníků České republiky, ČKTZJ - Česká komora tlumočníků znakového jazyka), s tlumočníky z evropských institucí, s představiteli tlumočnických agentur, s tlumočníky na volné noze i ve stálém pracovním poměru. Kromě toho sami studenti připravují týmové prezentace na konkrétní témata či řeší př́padové situace, s nimiž se jako konferenční tlumočníci zcela jistě setkají. 


\section{Závěrem}

Věř́m, že se nám na ÚTRL FF UK daří naše absolventy na jejich profesionální tlumočnickou kariéru doma i v zahraničí kvalitně připravit. To byl cíl všech vyučujících po celou dobu existence studijního oboru tlumočnictví zde v Praze, jehož 55. výročí založení jsme si v akademickém roce 2018/2019 také i tímto připomněli.

\section{BIBLIOGRAFIE}

Bauwelinck, Eric (2017) Voices from Above. The Calling of an Interpreter. A Journey from Onsite to Online Interpretation, 2. vydání Mastervoice.

Čeňková, Ivana (1993) 'Interprètes de conférence professionnels en République Tchèque : leurs acquis et défis', in XIII FIT World Congress „Translation - the vital link“, 6.-13. 8. 1993, Brighton, vol. 1, 339-342.

Čeňková, Ivana (1995) 'Le rôle des interprètes de conférence en Tchécoslovaquie et l'importance de leur formation professionnelle', Folia translatologica 2: 107-113.

Čeňková, Ivana (2000) 'Vivre une année académique avec The European Masters in Conference Interpreting', The Interpreters' Newsletter 10 : 33-46.

Čeňková, Ivana (2007a) 'Retour a pilotáž: každodenní realita pro konferenční tlumočníky v evropských institucích', in Juraj Dolník - Zuzana Bohušová - Anita Hutková (eds.). Translatológia a jej súvislosti 2. Banská Bystrica: Universita Mateja Bela, Filozofická fakulta, 97-112.

Čeňková, Ivana (2007b) 'Tlumočíme pro Evropskou unii aneb pohled z české kabiny', in Květuše Lepilová (ed.) Inovace postgraduálního vzdělávání učitelů ruštiny. CD - Repronis.

Čeňková, Ivana (2007c) 'Eurožargon z pohledu českého tlumočníka v Bruselu', in Translatologica Ostravensia. Ostrava: Universitatis Ostraviensis, 37-42.

Čeňková, Ivana (2008a) 'Vliv multikulturního kontextu na strategie tlumočníka při práci v institucích Evropské unie (př́ípadová studie z Plenárního zasedání Evropského parlamentu): Text - Kontext Makro-kontext', in Květuše Lepilová (ed.), Text a kontext, Brno: Repronis, 28-33.

Čeňková, Ivana (2008b) 'Retour et relais - un défi et une réalité quotidienne pour les interprètes de conférence au sein des institutions européennes', Forum, revue internationale d'interprétation et de traduction, 6(2), Presses de la Sorbonne Nouvelle - KSCI, 1-21.

Čeňková, Ivana (2010) 'Sight translation - Prima vista', in Yves Gambier - Luc van Doorslaer (eds.), Handbook of Translation Studies, Vol. 1, Amsterdam: John Benjamins Publishing, 320-323.

Čeňková, Ivana (2011) 'Les interprètes de langue tchèque au sein des institutions européennes et les défis de la présidence tchèque', in José Carlos Herreras (ed.), L'Europe des 27 et ses langues, Valenciennes, Collection Europe(s): Presses Universitaires de Valenciennes, 637-651.

Čeňková, Ivana (2015a) 'Relay Interpreting', in Franz Pöchhacker, Routledge Encyclopedia of Interpreting Studies, London/New York: Routledge Taylor \& Francis Group London and New York, 339-341.

Čeňková, Ivana (2015b) 'Omnipresent virtual reality and novel text formats interpreted in the 21th century', in Zuzana Bohušová - Mira Kadrič (eds.) Dolmetschen Interpreting. Translationswissenschaft und ihre Zusammenhänge / Translation Studies and its Contexts / Translatológia a jej súvislosti 6, Wien: Praesens Verlag, 133-140.

Donovan, Clare (2004) 'European Masters Project Group: Teaching Simultaneous Interpreting into a B Language', Interpreting 6(2): 205-216.

Godijns, Rita - Hinderdael, Michael (eds.) (2005) Directionality in Interpreting The 'Retour'or the Native?, Gent: Communication \& Cognition.

Gromová, Edita - Müglová, Daniela (2005) Kultúra - Interkulturalita - Translácia, Nitra: Univerzita Konštantína Filozofa.

Holečková, Marta Edith (2019) Příběh zapomenuté univerzity. Univerzita 17. listopadu (1961-1974) a její místo v československém vzdělávacím systému a společnosti, FF UK: Fontes. 
Seleskovitch, Danica - Lederer, Marianne (1989, 2. rozšířené vyd. 2002) Pédagogie raisonnée de l'interprétation, Paris: Didier Erudition.

Serrano, Dely (2002) 'Mladí vpřed, staří na svá místa', ToP (Tlumočení a překlad) 61: 4-9.

\section{Elektronické zdroje}

https://cs.wikipedia.org/wiki/Rada_vz\%C3\%A1jemn\%C3\%A9_hospod\%C3\%A1\%C5\%99sk\%C3\%A9 _pomoci [access: 29.11.2019].

https://cs.wikipedia.org/wiki/Marshall\%C5\%AFv_pl\%C3\%A1n [access: 30. 11. 2019].

https://www.nato.int [access: 30. 11. 2019].

https://europa.eu/european-union/index_cs [access: 30. 11.2019].

https://utrl.ff.cuni.cz/UTRLFF-1.html [access: 30. 11. 2019].

http://www.moderni-dejiny.cz/clanek/tzv-varsavska-smlouva-14-5-1955 [access: 30. 11. 2019].

EMCI Workshop (2002) Teaching Simultaneous Interpretation into a B language vol 1: https://www .emcinterpreting.org/emci_drupal_data/EMCI-TeachingSimultaneousIntoB-vol1.pdf [access: 29. 11. 2019].

EMCI Workshop (2005) Teaching Simultaneous Interpretation into a B language vol 2: https://www .emcinterpreting.org/emci_drupal_data/EMCI-TeachingSimultaneousIntoB-vol2.pdf [access: 29. 11. 2019].

Ztraceni v překladu, historii oboru připomíná stálá výstava ve Šporkově paláci: https://utrl.ff.cuni.cz /UTRLFF-447.html [access: 29. 11. 2019].

Prof. PhDr. Ivana Čeňková, CSc.

Ústav translatologie, Filozofická fakulta, Univerzita Karlova

ivana.cenkova@ff.cuni.cz 